\title{
MASTERY OF SCIENTIFIC ARGUMENTATION ON THE CONCEPT OF NEUTRALIZATION IN CHEMISTRY: A MALAYSIAN PERSPECTIVE
}

\author{
${ }^{1}$ Lee Ling Heng, ${ }^{2}$ Johari Surif, ${ }^{3}$ Cher Hau Seng \& \\ ${ }^{4}$ Nor Hasniza Ibrahim \\ ${ }^{1,2 \& 4}$ Faculty of Education, Universiti Teknologi Malaysia \\ ${ }^{3}$ Student Support Services, University of Sydney \\ ${ }^{1}$ Corresponding author: chua.heng@hotmail.com
}

\begin{abstract}
Purpose - Argumentative practices are central to science education, and have recently been emphasised to promote students' reasoning skills and to develop student's understanding of scientific concepts. This study examines the mastery of scientific argumentation, based on the concept of neutralisation, among secondary level science students, when engaged in individual and group argumentations.
\end{abstract}

Methodology - 356 form four science students were first randomly assigned to an argumentative condition, after their lesson on acids and bases, presented using the developed instructional materials. Each individual or group was then asked to answer an Open-ended Scientific Argumentation Test (OSAT). Discussions during group argumentations were observed and recorded. All the answers provided in the OSAT were then analysed based on their accuracy, the triplet relationship in chemistry and for the presence of argumentation elements. Observations from the group argumentations were transcribed and assessed.

Findings - The results show that in both argumentative conditions, most of the arguments constructed tend to consist of the elements of claim and evidence. The results also show that students who work in groups outperform students who work individually. As individuals, most of the arguments presented tend to be simple with reasoning 
at a macro-level. As groups, the arguments presented are more complex, where justifications are provided at the sub-micro and symbolic levels, and with fewer misconceptions. That is because group argumentation participants have the opportunity to share ideas, detect and correct each other's mistakes, seek explanations and explain ideas.

Significance - The study implies that group argumentation enhances students' argumentation and reasoning skills and improves their mastery of scientific concepts. In addition, this study also investigates students' performance from the Malaysian perspective.

Keywords: Misconceptions, neutralisation, scientific argumentation, triplet relationship.

\section{INTRODUCTION}

Scientific argumentation is a formal argumentation that is evidencebased (Schen, 2007) and involves a coordination of data, claim and evidence to generate valid knowledge (Chen, 2011; Driver, Newton \& Osborne, 2000). Nowadays, scientific argumentation is emphasised in science education due to its ability to promote students' reasoning skills and enhance their mastery of content knowledge. In Malaysia, scientific argumentation is emphasised through the adoption of reasoning skills in the Kurikulum Standard Sekolah Rendah (KSSR, 2011). Unfortunately, previous studies have shown that students from various academic levels have difficulty constructing scientific arguments that enhance their understanding of scientific knowledge (Heng, Johari, \& Yazid, 2012; Heng, Johari, \& Seng, 2015) and have problems mastering scientific argumentation (Dawson \& Venville, 2009; Heng, Johari, \& Seng, 2014; Heng et al., 2012; Nurul Aini, Zaidatun, \& Nurbiha, 2009; Zohar \& Nemet, 2002). Studies have also shown that students are given little opportunity to be involved in scientific argumentation in science classes (Heng \& Johari, 2013; Newton, Driver, \& Osborne, 1999; Simon, Erduran, \& Osborne, 2006).

In addition, most studies in the literature have used Toulmin's Argumentation Pattern (TAP) (Toulmin, Rieke, \& Janik, 1979) to assess the arguments constructed by students (Driver et al., 2000; 
Heng et al., 2014; Heng et al., 2012; Dawson \& Venville, 2009; Bell \& Linn, 2000; Erduran, Simon, \& Osborne, 2004; Evagorou, JiménezAleixandre, \& Osborne, 2012; Jiménez-Aleixandre, 2007; Osborne, Erduran, \& Simon, 2004). However, the TAP does not emphasise on the accuracy of the argument from a scientific perspective and has difficulty differentiating between the different argumentative elements: claim, data, warrant and backing (Driver et al., 2000). Hence, in this study, we propose a new argumentation framework that adopts three argumentative elements: claim, evidence and reasoning from McNeill and Pimentel's argumentation framework (McNeill \& Pimentel, 2010); and the fourth element, rebuttal from the TAP (Toulmin et al., 1979). The rebuttal element from the TAP is introduced in this study because it is seen as a quality indicator and represents higher cognitive skills among students (Clark \& Sampson, 2008; Erduran, 2007; Foong \& Daniel, 2013; Osborne et al., 2004; von Aufschnaiter, Erduran, Osborne \& Simon, 2008). The proposed argumentation framework is depicted in Figure 1, where the elements are defined as follows: a claim is a statement that answers a question or problem; an evidence is scientific data that supports the claim; reasoning provides a justification for why or how the evidence supports the claim; and a rebuttal is a statement that specifies the conditions under which the claim will not be true.

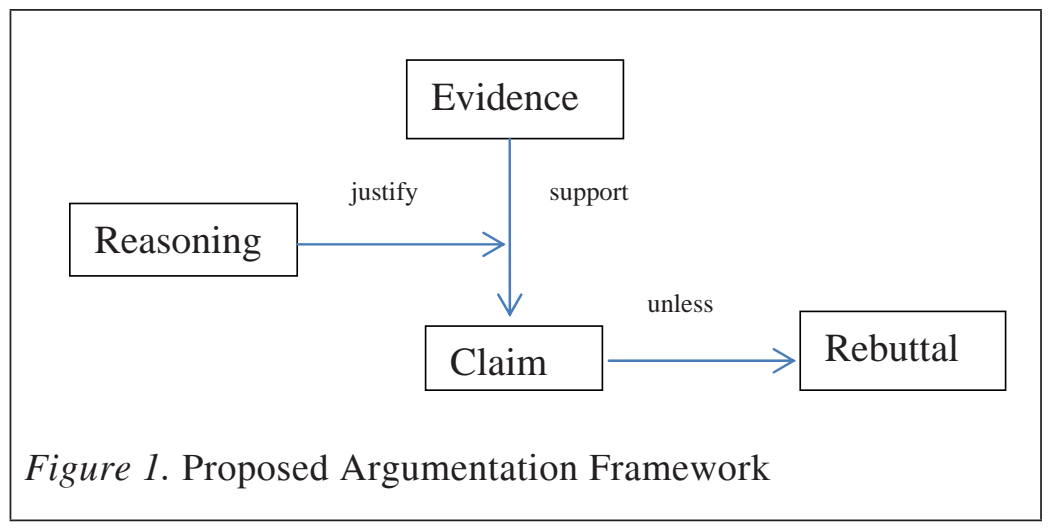

Using the proposed framework, students' arguments were then assessed based on the accuracy, the triplet relationship in chemistry and for the presence of argumentation elements. Accuracy is emphasised in this study, since it plays an important role in the 
learning and understanding process. Further, the existence of misconceptions in the construction of scientific arguments acts as a barrier to learning (Cetingul \& Geban, 2005; Heng \& Johari, 2014). The triplet relationship in chemistry, namely the macro-, the submicro and the symbolic representations (Gilbert \& Treagust, 2009; Johnstone, 1991) are also considered in this study. Often, students would perceive chemistry as a difficult and dull subject (Tsaparlis, Kolioulis \& Pappa, 2010) due to their lack of understanding among the three levels of representations (Johnstone, 1991). Therefore, students have to understand the link between the macro-, the sub-micro and the symbolic levels to learn, understand and grasp chemistry concepts (Beall, Trimbur, \& Weininger, 1994). Bucat and Mocerino (2009) and Johnstone (2000) also suggested that the sub-micro level should be knitted into the observable macro- and symbolic levels to enhance the understanding of chemistry concepts. Moreover, few studies have explicitly compared individual and group performance in scientific argumentation (Sampson \& Clark, 2009). Thus, this study examines students' mastery in scientific argumentation in both individual and group argumentation conditions. More specifically, we examine the mastery of scientific argumentation on the concept of neutralisation among Malaysian secondary level science students.

\section{METHODOLOGY}

\section{Research Design}

The study combines both qualitative and quantitative descriptive research. The quantitative component focuses on the mastery of scientific argumentation; while the qualitative component involves detailed analyses of the written tests and transcripts of observations during group argumentations, which support the quantitative data.

\section{Participants}

356 form four science students from five different schools participated in this study. Students in these five schools were taught by five different teachers, but using the same curriculum and the same developed instructional materials. At the end of the lessons, 
students' mastery of scientific argumentation was assessed using an open-ended test. All the participants were randomly divided into two groups to answer the test. 176 participants were involved in individual argumentation, answering the test without any discussion; while 45 groups of four participants $(45 \times 4=180)$ were group argumentation. Students' performance in both argumentative conditions was then compared, similar to the study conducted by Laughlin, Hatch, Silver and Boh (2006).

\section{Instrument}

To assess students' mastery of scientific argumentation when engaged in individual and group argumentations, participants were asked to complete an Open-ended Scientific Argumentation Test (OSAT) related to the concept of neutralisation. The OSAT was developed according to the syllabus and adapted from the Argumentation Instrument proposed by Sampson and Clark (2011). The OSAT has an introduction, which provides some information about the phenomenon being studied, followed by a diagram to assist students in answering questions related to scientific argumentation. The information provided in the OSAT is intended to help students engage in argumentative activities (von Aufschnaiter et al., 2008). In order to establish validity and reliability, the instrument was verified by two senior lecturers and a pilot study conducted. The Alpha-Cronbach value obtained from the pilot study was 0.892 .

\section{Data Collection and Analyses}

After seven lessons on acids and bases, participants were randomly assigned to one of two argumentation conditions to answer the OSAT within an allocated time. Students involved in individual argumentation worked alone, whereas students involved in group argumentation worked in groups of four. The discussions during group argumentations were observed and recorded. The students' mastery of scientific argumentation was then assessed based on the accuracy, the triplet relationship in chemistry and the argumentation elements used in the constructed arguments.

Students' arguments in OSAT were first examined to identify the presence of misconceptions. If the arguments consisted of any misconceptions, the arguments were classified as non-scientific. 
On the other hand, any arguments with the correct concepts and with no misconceptions were classified as scientific. The same argument was also re-examined using content analysis technique (Corbin \& Strauss, 2008) to gather detailed information related to the argumentation elements and the three levels of representations in chemistry. The number of scientific and non-scientific arguments and the number of argumentation elements used by students in both individual and group argumentations were then counted and presented as a percentage.

\section{Instructional Materials}

Instructional materials related to the concepts of neutralisation were developed based on the proposed argumentation framework. The concept of neutralisation was chosen because the Malaysian chemistry syllabus places great emphasis on it. The instructional materials were also designed to embed argumentative activities, such as discussing, questioning, evaluating and critising. During the lessons, students were required to present a claim for a phenomenon related to acids and bases and provide evidences and justifications to support their claim. In addition, students were encouraged to debate different claims and evidences and provide rebuttals.

\section{RESULTS AND DISCUSSION}

In this section, the mastery of scientific argumentation between students engaged in individual argumentation and group argumentation is discussed.

\section{The Mastery of Scientific Argumentation between Students Engaged in Individual Argumentation and Group Argumentation}

Figure 2 shows the percentage of scientific and non-scientific arguments constructed by students. It can be observed that $28.41 \%$ of non-scientific arguments were constructed by students engaged in individual argumentation and only $20 \%$ were constructed by students involved in group argumentation. This shows that students possessed some scientific knowledge on the concepts being studied. This differs from our previous study which concluded that students' 
mastery of scientific argumentation is weak (Heng et al., 2015, Heng et al., 2014; Heng, Johari \& Seng, 2013). This could be due to the instructional materials and lessons presented to the students prior to the OSAT, which allowed them to exercise their argumentation skills to enhance their content knowledge. This supports Kuhn's contention that argumentation skills are initially present, although not fully developed (Zohar \& Nemet, 2002). Thus, some guidance focusing on argumentation in the context of acids and bases, provided students with the opportunity to enhance both content knowledge and argumentation skills (Zohar \& Nemet, 2002). Besides, involvement in argumentative activities during the teaching and learning process has a positive impact on students' understanding and increases their academic achievement (Goh, Wong, \& Rosma, 2012).

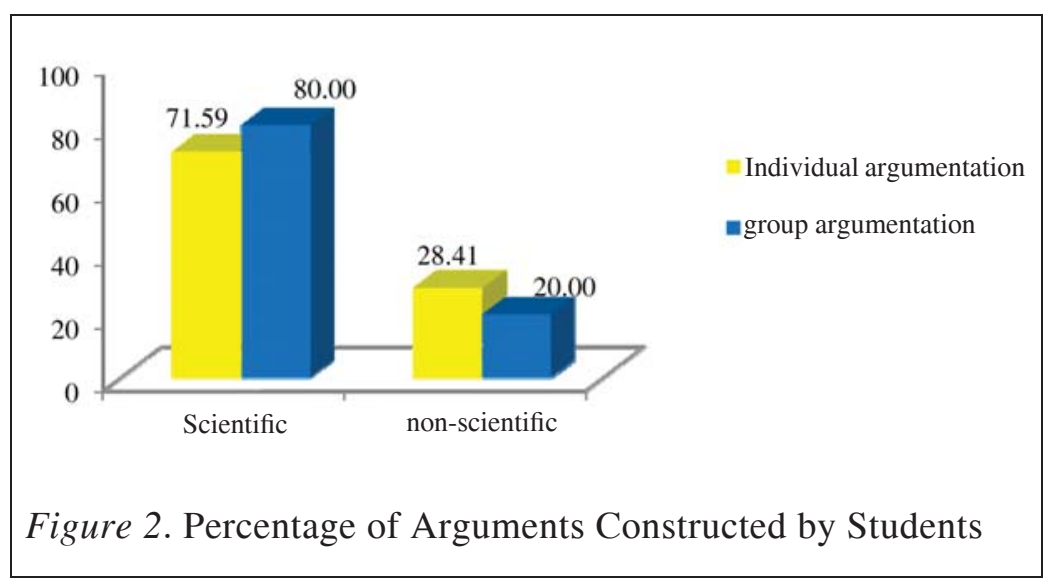

Figure 2 shows that students in group argumentation performed better than students in individual argumentation. This is in line with the study conducted by Barron (2000), which concluded that groups tend to perform better than individuals on complex tasks or tasks involving conceptual issues. Content analyses showed that arguments constructed by students in group argumentation consisted more justifications and were presented from different perspectives. Further, observations of group argumentations showed that students tend to explain ideas, combine different ideas, listen to each other's explanations and evaluate the validity of ideas. An example of a group argumentation is shown below. Note that all students' names are not their real names and the excerpts have been typed according to students' responses without any alterations to their grammar. 
Wei Yee: I think solution A will change colour. What do you think?

Juliana: I think solution A also.

Yusni: Why A change colour?

Alex: $\quad$ Because acid is added ...

Yusni: $\quad$ Ha...Must A? Why? ... Explain la...

Juliana: $\quad$ Mmm... because acid will react with alkali.

Wei Yee: Yes, react with alkali, it changes to yellow colour.

Alex: $\quad$ No! This not yet add acid, after adding acid, only it will change...right?

Juliana: Oh! Ya la...

Yusni: $\quad$ Change to what colour? Purple or pink?

Juliana: Wait! Acid react with alkali, it become neutral, right?

(Group argumentation 1)

From the transcript above, it can be observed that students who were involved in group argumentation shared ideas, detected and corrected other's mistakes, explained ideas and listened to other's explanations. This process has resulted in a deeper understanding of the concepts being studied and further increased the group's performance in scientific argumentation. In addition, it is observed that prompts and refutations during discussions allowed students to detect and correct mistakes and be aware of their own weaknesses in the constructed arguments, similar to the findings by Foong and Daniel (2013). This is also in line with several other studies, which reported that groups could promote students' scientific argumentation (Erduran, Ardac \& Guzel, 2006; McNeill \& Martin, 2011; Schwarz, Neuman, Gil \& Ilya, 2003).

\section{Scientific Argumentation Elements Constructed by Students Engaged in Individual Argumentation and Group Argumentation}

Regardless of individual or group argumentation, it can be observed from Table 1 that the elements of claim, evidence and reasoning are used more frequently in scientific arguments. This shows that most students could construct arguments with correct scientific concepts. Table 1 also shows that the percentage of the element of claim is the highest whereas the percentage of the element of rebuttal is the lowest. Eighty percent $(80 \%)$ of the arguments constructed by students in 
group argumentation consist of the element of claim, whereas only $71.59 \%$ of the arguments constructed by individual students have the element of claim. This indicates that group argumentative activities enhance students' ability to present accurate claims.

Further analyses on the non-scientific arguments show that there is a higher percentage of students who constructed correct claims in non-scientific arguments, as shown in Figure 3. This shows that students are unable to provide accurate scientific explanation for the claims presented although those claims were correct. This may be due to the existence of misconceptions or the lack of content knowledge about the phenomenon being studied. This finding supports the study by Mohd Ali, Salmiza, Zurida and Ahmad Nurulazam (2003) which reported that students were unable to provide accurate scientific explanation on the answers given even though the answers were correct.

\section{Table 1}

Percentage of Argumentation Elements Constructed by Students

\begin{tabular}{|c|c|c|c|c|c|c|}
\hline \multirow{3}{*}{ Elements } & \multicolumn{3}{|c|}{ Individual (\%) } & \multicolumn{3}{|c|}{ Group (\%) } \\
\hline & Scientific & Non- & No & Scientific & Non- & No \\
\hline & & Scientific & Answer & & Scientific & Answer \\
\hline Claim & 71.59 & 28.41 & 0.00 & 80.00 & 20.00 & 0.00 \\
\hline Evidence & 64.20 & 21.02 & 14.78 & 77.78 & 13.33 & 8.89 \\
\hline \multicolumn{7}{|l|}{ Reasoning } \\
\hline Macro- only & 58.52 & 21.02 & 5.69 & 40.00 & 11.11 & 4.44 \\
\hline $\begin{array}{l}\text { Macro- and sub- } \\
\text { micro }\end{array}$ & 6.25 & 5.11 & & 22.22 & 6.67 & \\
\hline Macro- and symbolic & 2.27 & 0.00 & & 6.67 & 0.00 & \\
\hline $\begin{array}{l}\text { Macro-, sub-micro } \\
\text { and symbolic }\end{array}$ & 1.14 & 0.00 & & 6.67 & 2.22 & \\
\hline Rebuttal & 3.41 & 0.57 & 96.02 & 4.44 & 0.00 & 95.56 \\
\hline
\end{tabular}

As for the evidence element, the percentage used is lower than the claim element, as evident from Table 1 . This is because students tend to use their own personal belief when presenting scientific arguments. This also shows that students have difficulties in differentiating between factual data and opinion. Similar to the findings by Sadler, Chambers and Zeidler (2004), students failed to use the appropriate data and scientific knowledge to support their claims. 


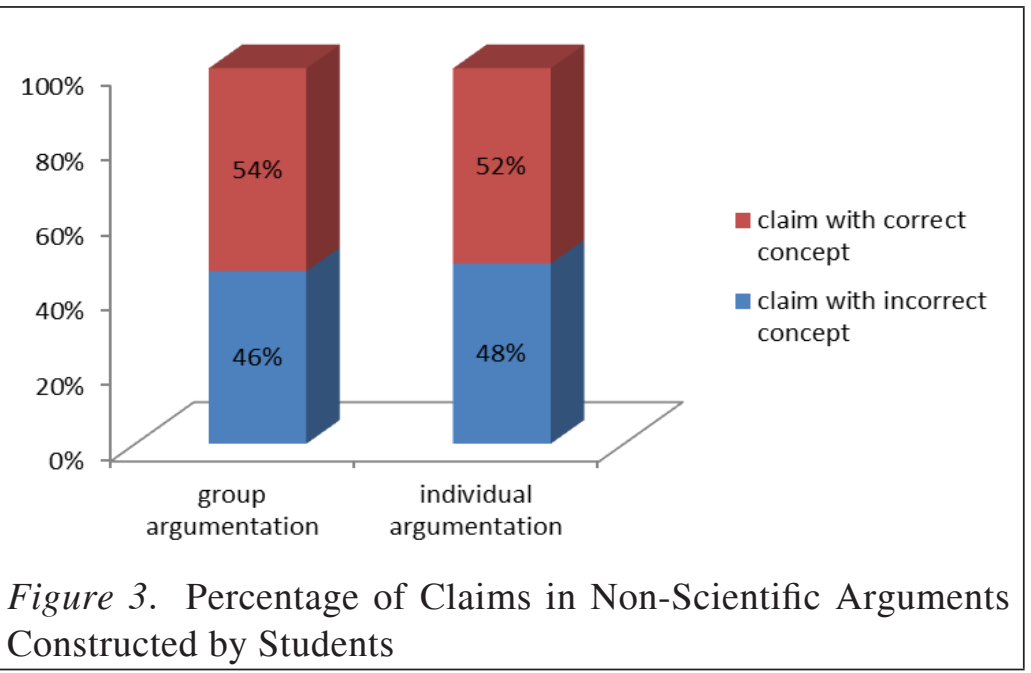

In terms of the reasoning element, Table 1 shows that the element is mainly used at the macro-level (58.52\% in individual argumentation and $40 \%$ in group argumentation). This shows that students could only construct simple arguments and lacked the ability to provide explanations at the sub-micro and symbolic levels, which is in line with the conclusions made by Dawson and Venville (2009), Heng et al. (2012) and Sia, Treagust and Chandrasegaran (2012). This may be due to the low exposure to different levels of representations in science classes, causing students to learn chemistry concepts at the three levels separately and in a discrete manner (Treagust, Chittleborough \& Mamiala, 2003). This finding corroborates findings by Winnie and Mohammad Yusof (2012), which reported that most teachers tend to ask questions at the symbolic or macrolevels and rarely at the sub-micro level. Besides, Table 1 also shows that the percentage for the reasoning element at the sub-micro and symbolic levels in group argumentations is higher than that of individual argumentations. This shows that collaborations through group argumentations, which involve the sharing of ideas, asking questions, explaining and listening to each other's explanations, promote a deeper understanding of scientific concepts. These findings also corroborate the study by Barron (2000) and Mason (1998), which reported that group performance is much better than individual performance, especially for complex assignments. This is because group argumentations make argument generation a social as well as a cognitive activity (Venville \& Dawson, 2010). 
Based on Table 1, about $95 \%$ of the arguments constructed did not have the element of rebuttal. It is observed that students could not provide statements that specify the conditions under which a claim will not be true. As a result, most of the arguments presented are considered simple, since rebuttal is seen as a quality indicator and an indicator for complex arguments (Erduran, 2007; Osborne et al., 2004; von Aufschnaiter et al., 2008). This result aligns with many studies which report that students' arguments tend to be simple, consisting of only one justification with a simple structure (Dawson \& Venville, 2009; Heng et al., 2012; Osborne et al., 2004; Wu \& Tsai, 2007). This may be caused by the lack of background knowledge about the structure of scientific arguments, as the instructional materials did not cover the argumentation structure.

\section{CONCLUSION}

This study shows that form four science students could construct arguments with the correct scientific concepts, which is in line with the policy introduced by the Ministry of Education, Malaysia where thinking habits among students are emphasised through the practice of higher order thinking. However, regardless of the argumentation condition, the contents of the arguments were mostly constructed at a macro-level and were simple in terms of the structure. This indicates that students are weak in their understanding of the link between the macro-, sub-micro and symbolic levels. In order to ensure a better understanding of scientific concepts, science teachers need to emphasise on the linkage among the three levels of representations in chemistry. In addition, the findings show that students in group argumentation outperformed students in individual argumentation. This suggests that group argumentative activities, such as discussing, questioning, evaluating and criticising improve students' scientific argumentation skills, and thus should be given priority in the teaching and learning of science.

All in all, the teaching and learning of science needs to focus on argumentation structures and the criteria for distinguishing between good and bad arguments. This will allow students to exercise their argumentative skills and hence, improve their 
mastery of scientific argumentation. This will also nurture the students' reasoning skills and content knowledge, which would enhance their academic achievement.

\section{ACKNOWLEDGMENTS}

The authors would like to express their appreciation to the Ministry of Education and Universiti Teknologi Malaysia for the grant R.J130000.7831.4F414 which is used to support this study.

\section{REFERENCES}

Barron, B. (2000). Problem solving in video-based microworlds: Collaboration and individual outcomes of high-achieving sixth grade students. Journal of Educational Psychology, 92(2), 391-398. doi: 10.1037/0022-0663.92.2.391

Beall, H., Trimbur, J., \& Weininger, S. J. (1994). Mastery insight and the teaching of chemistry. Journal of Science Education and Technology, 3(2), 99-105. doi: 10.1007/BF01575189

Bell, P., \& Linn, M. C. (2000). Scientific arguments as learning artifacts: Designing for learning from the web with KIE. International Journal of Science Education, 22(8), 797- 817. doi: 10.1080/095006900412284

Bucat, B., \& Mocerino, M. (2009). Learning at the sub-micro level: Structural representations. In J. K. Gilbert \& D. Treagust (Eds.), Multiple representations in chemical education (pp. 11-29). Dordrecht, the Netherlands: Springer.

Cetingul, P. I., \& Geban, O. (2005). Understanding of acid-base concept by using conceptual change approach. H. U. Journal of Education, 29, 69-74. Retrieved from http://www.efdergi. hacettepe.edu.tr

Chen, Y. C. (2011). Examining the integration of talk and writing for student knowledge construction through argumentation. (Unpublished doctoral dissertation). The University of Iowa, Iowa City, United States of America.

Clark, D. B., \& Sampson, V. D. (2008). Assessing dialogic argumentation in online environments to relate structure, grounds, and conceptual quality. Journal of Research in Science Teaching, 45(3), 293-321. doi: 10.1002/tea.20216 
Corbin, J., \& Strauss, A. (2008). Basics of qualitative research: Techniques and procedures for developing grounded theory (3rd ed.). Thousand Oaks: Sage Publications.

Dawson, V., \& Venville, G. J. (2009). High-school student's informal reasoning and argumentation about biotechnology: An indicator of scientific literacy? International Journal of Science Education, 31(11), 1421-1445. doi: 10.1080/09500690801992870

Driver, R., Newton, P., \& Osborne, J. (2000). Establishing the norms of scientific argumentation in classrooms. Science Education, 84(3), 287-312. doi: 10.1002/(SICI)1098237X(200005)84:3<287::AID-SCE1>3.0.CO;2-A

Erduran, S. (2007). Methodological foundations in the study of argumentation in science classrooms. In S. Erduran \& M. P. Jiménez-Aleixandre (Eds.), Argumentation in science education: Perspectives from classroom-based research ( $\mathrm{pp}$. 47-69). Dordrecht, the Netherlands: Springer.

Erduran, S., Ardac, D., \& Guzel, B. Y. (2006). Learning to teach argumentation: Case studies of pre-service secondary science teachers. Eurasia Journal of Mathematics, Science and Technology Education, 2(2). Retrieved from http://www. ejmste.com/022006/d1.pdf

Erduran, S., Simon, S., \& Osborne, J. (2004). Taping into argumentation: Developments in the application of Toulmin's argumentation pattern for studying science discourse. Science Education, 88(6), 915-933. doi: 10.1002/sce.20012

Evagorou, M., Jiménez-Aleixandre, M. P., \& Osborne, J. (2012). 'Should we kill the grey squirrels?' A study exploring students' justifications and decision-making. International Journal of Science Education, 34(3), 401-428. doi: 10.1080/09500693.2011.619211

Foong, C. C., \& Daniel, E. G. S. (2013). Students' argumentation skills across two socio-scientific issues in a Confucian classroom: Is transfer possible? International Journal of Science Education, 35(14), 2331-2355. doi: 10.1080/09500693.2012.697209

Gilbert, J. K., \& Treagust, D. (Eds.). (2009). Multiple representations in chemical education. Dordrecht, the Netherlands: Springer.

Goh, P. S. C., Wong, K. T., \& Rosma O. (2012). Student-teachers' approaches to learning, academic performance and teaching efficacy. Malaysian Journal of Learning and Instruction, 9, 31-46. 
Heng, L. L., \& Johari S. (2013). Penghujahan saintifik: Memahami perlaksanaannya dalam proses pengajaran dan pembelajaran kimia [Scientific argumentation: Understanding the process of implementation of teaching and learning of chemistry]. Jurnal Teknologi (Social Sciences), 65(1), 1-8. doi: 10.11113/ jt.v65.1549

Heng, L. L., \& Johari S. (2014). Memahami kesilapan pelajar dalam membentuk penghujahan saintifik [Understanding students' mistakes in constructing scientific arguments]. Sains Humanika, 2(1), 23-33. Retrieved from http://www. sainshumanika.utm.my/index.php/sainshumanika/article/ view/373

Heng, L. L., Johari S., \& Seng, C. H. (2013, July). Students' performance in scientific argumentation: Individual versus group. Paper presented at the International Conference on Education, Psychology and Society (ICEPAS), Bangkok, Thailand.

Heng, L. L., Johari S., \& Seng, C. H. (2014). Individual versus group argumentation: Student's performance in a Malaysian context. International Education Studies, 7(7), 109-124. doi: 10.5539/ies.v7n7p109

Heng, L. L., Johari S., \& Seng, C. H. (2015). Malaysian students' scientific argumentation: Do groups perform better than individuals? International Journal of Science Education, 37(3), 505-528. doi: 10.1080/09500693.2014.995147

Heng, L. L., Johari S., \& Yazid A. M. (2012, September). Penguasaan penaakulan saintifik pelajar pendidikan opsyen sains terhadap konsep asid dan bes [Mastery of scientific reasoning among science option students on acids and bases concepts]. Paper presented at the International Seminar in Science and Mathematics Education (ISSME), Johor, Malaysia.

Jiménez-Aleixandre, M. P. (2007). Designing argumentation learning environments. In S. Erduran, \& M. P. JiménezAleixandre (Eds.), Argumentation in science education: Perspectives from classroom-based research (pp. 91-116). Dordrecht, the Netherlands: Springer. doi: 10.1007/978-14020-6670-2_5

Johnstone, A. H. (1991). Why is science difficult to learn? Things are seldom what they seem. Journal of Computer Assisted Learning, 7(2), 75-83. doi: 10.1111/j.1365-2729.1991.tb00230.x 
Johnstone, A. H. (2000). Teaching of chemistry-Logical or psychological? Chemistry Education: Research and Practice in Europe, 1(1), 9-15. doi: 10.1039/A9RP90001B

Kurikulum Standard Sekolah Rendah (KSSR) [Standard Curriculum for Primary Schools]. (2011). Retrieved from http://web.moe. gov.my.

Laughlin, P., Hatch, E., Silver, J., \& Boh, L. (2006). Groups perform better than the best individuals on letters-to-numbers problems: Effects of group size. Journal of Personality and Social Psychology, 90(4), 644-651. doi: 10.1037/00223514.90.4.644

Mason, L. (1998). Sharing cognition to construct scientific knowledge in school context: The role of oral and written discourse. Instructional Science, 26, 359-389. doi: 10.1023/A:1003103213786

McNeill, K. L., \& Martin, D. M. (2011). Claims, evidence, and reasoning: Demystifying data during a unit on simple machines. Science and Children, 48(8), 53. Retrieved from http:// connection.ebscohost.com/c/science-experiments/59972817/ claims-evidence-reasoning-demystifying-data-during-unitsimple-machines

McNeill, K. L., \& Pimentel, D. S. (2010). Scientific discourse in three urban classrooms: The role of the teacher in engaging high school students in argumentation. Science Education, 94(2), 203-229. doi: 10.1002/sce.20364

Mohd Ali S., Salmiza S., Zurida H. I., \& Ahmad Nurulazam M. Z. (2003). Kefahaman dan kerangka alternatif konsep haba di kalangan pelajar-pelajar tingkatan empat/ Understanding and alternative framework on the concept of heat among form four Students. The Classroom Teacher, 8(1), 41-61.

Newton, P., Driver, R., \& Osborne J. (1999). The place of argumentation in the pedagogy of school science. International Journal of Science Education, 21(5), 553-576. doi: 10.1080/095006999290570

Nurul Aini M. D., Zaidatun T., \& Nurbiha A. S. (2009). Development of inquiry-based learning website for enhancing scientific reasoning skill. Paper presented at the Education Postgraduate Research Seminar, Johor, Malaysia.

Osborne, J., Erduran, S., \& Simon, S. (2004). Enhancing the quality of argumentation in school science. Journal of Research in Science Teaching, 41(10), 994-1020. doi: 10.1002/tea.20035 
Sadler, T. D., Chambers, F. W., \& Zeidler, D. L. (2004). Student conceptualizations of the nature of science in response to a socioscientific issue. International Journal of Science Education, 26(4), 387-409. doi: 10.1080/0950069032000119456

Sampson, V., \& Clark, D. B. (2009). The impact of collaboration on the outcomes of scientific argumentation. Science Education, 93(3), 448-484. doi: 10.1002/sce.20306

Sampson, V., \& Clark, D. B. (2011). A comparison of the collaborative scientific argumentation practices of two high and two low performing groups. Research in Science Education, 41, 6397. doi: 10.1007/s11165-009-9146-9

Schen, M. S. (2007). Scientific reasoning skills development in the introductory biology courses for undergraduates. (Unpublished doctoral dissertation). The Ohio State University, Columbus, United States of America.

Schwarz, B. B., Neuman, Y., Gil, J., \& Ilya, M. (2003). Construction of collective and individual knowledge in argumentative activity. The Journal of the Learning Science, 12(2), 219-256. doi: 10.1207/S15327809JLS1202_3

Sia, D. T., Treagust, D. F., \& Chandrasegaran, L. (2012). High school students' proficiency and confidence levels in displaying their understanding of basic electrolysis concepts. International Journal of Science and Mathematics Education, 10, 13251345. doi: 10.1007/s10763-012-9338-z

Simon, S., Erduran, S., \& Osborne, J. (2006). Learning to teach argumentation: Research and development in the science classroom. International Journal of Science Education, 28(23), 235-260. doi: 10.1080/09500690500336957

Toulmin, S., Rieke, R., \& Janik, A. (1979). An introduction to reasoning. New York: Macmillan Publishing.

Treagust, D. F., Chittleborough, G., \& Mamiala, T. L. (2003). The role of submicroscopic and symbolic representations in chemical explanations. International Journal of Science Education, 25(11), 1353-1368. doi: 10.1080/0950069032000070306

Tsai, C. C. (1999). Overcoming junior high school students' misconceptions about microscopic views of phase change: A study of an analogy activity. Journal of Science Education and Technology, 8(1), 83-91. doi: 10.1023/A:1009485722628 
Tsaparlis, G., Kolioulis, D., \& Pappa, E. (2010). Lower-secondary introductory chemistry course: A novel approach based on science-education theories with emphasis on the macro approach, and the delayed meaningful teaching of the concepts of molecule and atom. Chemistry Education Research and Practice, 11(2), 107-117. doi: 10.1039/c005354f

Venville, G. J., \& Dawson, V. M. (2010). The impact of a classroom intervention on grade 10 students' argumentation skills, informal reasoning, and conceptual understanding of science. Journal of Research in Science Teaching, 47(8), 952-977. doi: 10.1002/tea.20358

von Aufschnaiter, C., Erduran, S., Osborne, J., \& Simon, S. (2008). Arguing to learn and learning to argue: Case studies of how students' argumentation relates to their scientific knowledge. Journal of Research in Science Teaching, 45(1), 101-131. doi: 10.1002/tea.20213

Winnie, S. S. L., \& Mohammad Yusof A. (2012). A preliminary study of chemistry teachers'question in inquiry teaching. Paper presented at the Seminar Kebangsaan Majlis Dekan Pendidikan IPTA, Johor, Malaysia.

Wu, Y. T., \& Tsai, C. C. (2007). High school students' informal reasoning on a socio-scientific issue: Qualitative and quantitative analyses. International Journal of Science Education, 29(9), 1163-1187. doi: 10.1080/09500690601083375

Zohar, A., \& Nemet, F. (2002). Fostering students' knowledge and argumentation skills through dilemmas in human genetics. Journal of Research in Science Teaching, 39(1), 35-62. doi: 10.1002/tea. 10008 